\title{
Orman köylerinde arıcılık sorunları ve çözüm önerileri (Trabzon Orman Bölge Müdürlüğü örneği)
}

\author{
Beekeeping problems and solution suggestions in forest villages (Trabzon Regional \\ Directorate of Forestry example)
}

Ayşe KÜÇÜK ${ }^{1}$
Arife SAYLAM

Akin $\mathrm{AL}^{2}$ (D)

Orhan Yasin ŞAHINNOĞLU²

${ }^{1}$ Doğu Karadeniz Ormancılık Araştırma Enstitüsü Müdürlüğü, Trabzon

${ }^{2}$ Orman Genele Müdürlüğg̈, Trabzon Orman Bölge Müdürlüğü, Trabzon

Sorumlu yazar (Corresponding author) Ayşe KÜÇÜK

aysecakmakkucuk@ogm.gov.tr

Geliş tarihi (Received)

20.09.2021

Kabul Tarihi (Accepted)

24.01.2022

Sorumlu editör (Corresponding editor) Ersin YILMAZ

eyilmaz33@gmail.com

Atıf (To cite this article): Küçük, A. , Saylam, A. , Al, A. \& Şahinoğlu, O. Y. (2022). Orman köylerinde arıcıllk sorunları ve çözüm önerileri (Trabzon Orman Bölge Müdürlüğü örneği) . Ormancılık Araștırma Dergisi , 9 (2), 122-134 . DOI: 10.17568/ogmoad.997825

\section{$\ddot{O} z$}

Bu çalışma da; Trabzon Orman Bölge Müdürlüğü sorumluluk alanında yer alan Trabzon, Rize, Gümüşhane ve Bayburt illerindeki orman köylerinde, ORKÖY kredisi ile desteklenen ve desteklenmeyen 523 işletmede arı ve arı ürünleri üretimi süreci incelenmiş olup, yüzyüze anket yöntemiyle karş1laştıkları sorunlar belirlenmiştir. Arıcıların cinsiyeti, yaşı, eğitimi, ikameti, geçim kaynakları, sosyal güvence durumları, aylık ve yıllık gelirlerinin yanı sıra sabit ve gezginci olma durumları incelenmiştir. Üretim sürecinde, donanım eksiklikleri, ana arı problemleri, arı hastalıkları, kışlatma kayıpları, arı konaklama yeri problemleri, yaban hayvanlarından ve tarım ilaçlarından zarar görme durumları, pazarlama problemleri ve eğitim talepleri belirlenmiş olup arıcıların sorunlarına çözüm önerileri getirilmiştir. Ayrıca elde edilen veriler ile ORKÖY fenni arıcılık kredilerine düzenlenme getirilebilir.

Anahtar Kelimeler: Arıcılık, arıcılık sorunları, Trabzon Orman Bölge Müdürlüğü, orman köyü, bal

\begin{abstract}
In this study, the beekeeping and bee products production process in 523 enterprises supported or not supported with ORKOY loans in forest villages in Trabzon, Rize, Gümüşhane, and Bayburt provinces under the Trabzon Regional Directorate of Forestry were examined. The problems they encountered were determined by the face-to-face survey method. Beekeepers' gender, age, education, residence, livelihoods, social security status, monthly and annual incomes as well as fixed and mobile status were examined. During the production process, equipment deficiencies, queen bee problems, bee diseases, wintering losses, bee accommodation problems, damage from wild animals and pesticides, marketing problems and training demands were determined and solutions were proposed for the problems of beekeepers. In addition, with the data obtained, ORKOY scientific beekeeping loans can be regulated.
\end{abstract}

Keywords: Apiculture, apiculture problems, Trabzon Regional Directorate of Forestry, forest village, honey 


\section{Giriş}

Arılar; Hymenoptera (Zar kanatlılar) takımında, Apidae familyasının Apis cinsini oluşturan böceklerdir. Yeryüzünde 25.000 kadar tanımlanmış ar1 türü bulunmaktadır. Balarısı (Apis mellifera) dışındaki türler yaban arıları olarak bilinmektedir. Arılar koloniler şeklinde yaşamlarını sürdürür. Koloni; Bir ana arı, onbinlerce işçi arı ve yüzlerce erkek arıdan oluşan ve bir kovan içerisinde ortak yaşayan arı ailesini tanımlamak için kullanılır. (Doğaroğlu ve Doğaroğlu, 2015).

Dünyada ekonomik değeri yüksek olarak gösterilen batı arılarının en önemlileri; Esmer arı (Apis mellifera mellifera), İtalyan arıs1 (Apis mellifera ligustica), Karrniyol arıs1 (Apis mellifera carnica) ve Kafkas arısıdır (Apis mellifera caucasica)'dır (Güler, 2017).

Her canlı türünde olduğu gibi bal arılarının (Apis mellifera mellifera) da yaşama gücü ve verim düzeyini olumsuz yönde etkileyen hastalık ve zararlıları vardır. Kovanın materyali, iklim şartları, besleme, ana arı yaşı, ana arı kalitesi, koloni dinamiği, temel petek, çevre kirliliği, aşırı 1S1 dalgalanmaları, nektar ve polen kaynakları ve çeşitliliği gibi faktörler uygun olmadığında yetiştirilmeye zorlanan arı kolonileri verimli olmadıkları gibi hastalık etmeni için kolayca bulaşabilecekleri birer kaynağa dönüşürler. Ar1 hastalık ve parazitleri etmenlerine göre bakteriyel, fungal, protozoan, viral ve paraziter olmak üzere 5 grupta değerlendirilir (Güler, 20217). Bunlar; Amerikan Yavru Çürüklüğü, Avrupa Yavru Çürüklüğü, Septisemi Hastalığı, Nosema Hastalığı, Varroa Akarı, Arı Felcidir.

Arıcılık: Bal arısı kolonilerinin bulundukları yörelere göre nektar akımının bol olduğu dönemlerde tarlacı işçi arı mevcudunun en üst düzeye çıkarılması ve bu kolonilerin bal, polen, arı sütü vb. üretimi ve bitkilerin tozlaşması amacıyla kullanıldığı tarımsal bir faaliyettir. Flora çeşitliliğ ve potansiyeli verimli yetiştiricilik için önemli olsa da arıcılık bir beceri işi olduğu kadar her türlü teknoloji ve bilimsel gelişmeden yararlanmayı gerekli kılan bir sektördür (Güler, 2017). Arıcılık faaliyetleri neticesinde bal arisından; bal, polen, propolis, arı sütü, arı zehiri, bal mumu gibi insan sağlığı açısından önemli arı ürünleri elde edilirken apiterapi uygulamaları ise yaygınlaşmaktadır.

Arıcılık faaliyetleri; az topraklı veya topraksız çiftçilere gelir sağlayabilen, toprağa bağlı kalmadan düşük yatırım, işgücü girdisi ile diğer tarımsal faaliyetleri aksatmadan yapılan ve yüksek gelir olanakları sunan tarımsal bir iş koludur. Dört mev- simin bir arada yaşandığı Türkiye ekolojik bölgelerinde ilkbahar ve yaz mevsiminde binlerce çeşit bitkinin çiçek açmasıyla üretilen nektar servetini arılar sayesinde bal ürününe dönüştürürken hem ülke ekonomisine katkı sağlamakta hem de kullanılamayan işgücüne de değerlendirme olanağı sunmaktadir (DOKAP, 2014).

Arıcılığın güncel durumuna baktığımızda; Dünya G1da Örgütü 2015 yılı (FAO) verilerine göre Dünyada 89.011.672 adet koloni mevcut olup, 1.852 .752 ton bal elde edilmektedir. Bal üretimi bakımından Çin 1.sırada Türkiye 2. sırada yer alırken, koloni varlığı bakımından Hindistan 1. sırada, Çin 2. s1rada ve Türkiye 3. sırada yer almaktadır (URL 1, 2015).

Türkiye' deki koloni varlığgna bağlı olarak bal verimine baktığımızda 2017 yılında 7.991 .072 adet koloni ile 114.471 ton bal üretimi yapılırken, 4.488 ton da balmumu üretimi yapılmaktadır. Çalışma alanımızda bulunan Trabzon, Rize, Gümüşhane ve Bayburt illerinin kovan başı bal verimine baktığ1mizda; Trabzon için 10,70 kg, Rize için 12,3 kg, Gümüşhane için 17,34 kg ve Bayburt için de 5,65 kg olarak hesaplanmıştır (URL 2, 2018).

Türkiye ekolojik olarak arıcılığa çok uygun bir doğaya sahip olmasına rağmen maalesef potansiyelinin çok azını kullanmaktadır. Ayrıca arıcılık yapan işletmelerde verim de oldukça düşüktür (Uzundumlu ve ark., 2011).

Arıcıların arı ve arı ürünleri üretiminde karşılaştıkları sorunlar sonucunda arıcılık mesleği yeterince gelişememiş olup, kırsalda sektör olarak gerçek değerine ulaşamamıştır. $\mathrm{Bu}$ sorunların başlıcaları; kırsaldaki ailelelerin demografik durumu, üretim, konaklama, pazarlama, arı hastalıkları, kredi ile arıcılık bilgi ve deneyiminin yeterli olmamasından kaynaklıdır.

Arıcılık sektörünün karşılaştığı sorunların devlet ve özel sektör tarafından çözümüne yönelik olarak birçok alanda çalışmalar yapılmaktadır.

OGM bünyesinde, Daire Başkanlığı şeklinde hizmet veren ORKÖY, ormanların korunması, geliştirilmesi, işletilmesi ve genişletilmesi hedeflerine ulaşılmasını sağlamak için, ormanların içinde veya bitişiğinde yaşayan köy halkının kalkınmalarına katkıda bulunmak suretiyle, ormanlar üzerindeki olumsuz etkilerini azaltmak ve üretici durumuna geçirmek amacıyla 1970'li yılların başında Orman Köy İlişkileri Genel Müdürlüğü (ORKÖY) kurulmuş olup Orman Köylülerinin Kalkındırılmalarının Desteklenmesi Faaliyetlerine İlişkin yasa çıkarılmış ve ORKÖY Fonu tesis edilmiştir. ORKÖY 
tarafından orman köylülerinin kalkındırılmasının desteklenmesi amaciyla sosyal ve ekonomik nitelikli kredilerle orman köylüsü desteklenmektedir. ORKÖY tarafından 2017 yılında tutarı 14.000 TL, \%20 hibe oranıyla, faizsiz, geri ödemeli Fenni Ar1c1lık kredisi uygulanmaktadır (URL 3, 2018).

Arıcılık sektörünün geliştirilmesi kapsamında Orman ve Su İşleri Bakanlığı’nın İlgili Genel Müdürlüklerince ağaçlandırma, erozyon kontrolü, Mera 1slahı, üretim ve bakım gibi, yapılacak proje ve çalışmalarda arıcılığa uygun vejetasyonun korunmaS1, geliştirilmesi, arıcılık amaçlı fonksiyonel planların hazırlanması, gezginci arıcıların konaklaması ile ilgili düzenlemeler, orman ekosistemlerinin ve biyolojik çeşitliliğin korunması konularında yapılacak çalışmaların uygulama esaslarını kapsamaktadir (Anonim 1, 2017).

Ayrıca yürürlükte olan Arıcılık Yönetmeliği’nde Çevre ve Orman Bakanlığı ve Orman Genel Müdürlüğü açısından ilişkisine baktığımızda 22 Mart 2012 tarih ve 28241 sayılı Resmi Gazete ile değişiklik yapılmıştır. Çevre ve Orman Bakanlığg ile Türkiye Arı Yetiştiricileri Merkez Birliğinin “Arıcılığın Geliştirilmesi” kapsamında yürütecekleri çalışmalara ilişkin protokol düzenlenmiştir. Tarım ve Orman Bakanlığınca; 2013-2018 yılları arasında arıcılık ve bal üretiminin desteklenmesi amacıyla Trabzon Orman Bölge Müdürlüğü sınırları içerisinde 5930 ha'lık alanda 15 adet bal ormanı tesis edilmiştir (URL 4, 2018).

Bu çalışmada; Trabzon Orman Bölge Müdürlüğü sorumluluk alanında yer alan orman köylerinde, ORKÖY tarafından arı ve arı ürünleri üretimi için desteklenen ve desteklenmeyen işletmelerin üretim süreçleri incelenmiş olup karşılaştıkları problemler tespit edilmiş ve bu problemlere çözüm önerileri getirilmeye çalışılmıştır. Ayrıca arı ve arı ürünleri üretimi yapan orman köylüleri ile sürdürülebilir ormancılık prensipleri doğrultusunda sağlıklı ilişkiler kurulması ve kamusal alanda çözüme katkı koyabilecek politikaların oluşturulmasını sağlıyacak öneriler sunulmuştur.

\section{Materyal ve Yöntem}

Çalışmada kayıtsal veriler 2015 yılı itibariyle; Orman Genel Müdürlüğü’nün Orman Köyleri Bilgi Sistemi (ORKBİS)'nden alınmış olup, Trabzon ilinde 357, Rize ilinde 127, Gümüşhane ilinde 250 ve Bayburt ilinde 41 adet orman köyü olduğu belirlenmiştir (URL 5, 2015), (Şekil 1).

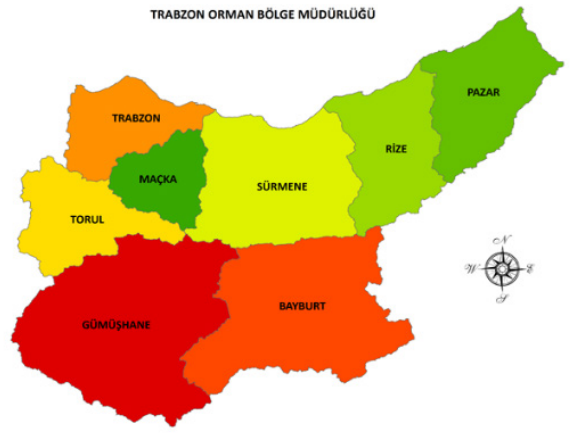

Şekil 1. Çalışma alanı

Figure 1. Study area

Trabzon Orman Bölge Müdürlüğü, ORKÖY Şube Müdürlüğü kayıtlarından, 2012-2016 yılları arasında Trabzon ilinde 171, Rize ilinde 146, Gümüşhane ilinde 56 ve Bayburt ilinde 48 olmak üzere toplam 421 aile işletmesi Fenni Arıcılık Kredisi ile desteklenmiştir (Anonim 2, 2015).

Tarım İl Müdürlüklerinin Arıcılık Kayıt Sisteminden (AKS); Trabzon, Gümüşhane, Rize ve Bayburt illerindeki orman köylerinde bulunan arı ve ar1 ürünleri üretimi yapan işletme sayıları tespit edilmiştir. Arı Yetiştiricileri ve Türkiye Bal Üreticileri Merkez Birliklerinden bu illerdeki Arıcı Kayıt Asil (30 adet kovan ve fazlasi) ve Yedek (1-29 adet kovan) listelerinden orman köylerindeki arı ve arı ürünleri üretimi yapan işletme sayıları kovan gruplarına göre listelenmiştir. Tüm toplanan verilerden Trabzon Orman Bölge Müdürlüğü sınırları içerisinde bulunan orman köylerindeki ORKÖY Fenni Arıcılık kredisi ile desteklenen ve desteklenmeyen arı ve arı ürünleri üretimi yapan işletmelerin sayıları belirlenip kovan adetlerine göre grupland1rilmıştır.

İşletme büyüklükleri kovan sayısı bakımından üç gruba ayrılmış. Bu gruplama;

1. Grup: 1-20 kovan,

2. Grup: 21-40 kovan,

3. Grup: $41 \leq+$ kovan şeklindedir.

$\mathrm{Bu}$ gruplamaya göre örneklem büyüklüğü tespit edilmiş olup her gruptan alınacak örneklerin belirlenmesinde tümünün anket kapsamına girme ihtimalinin eşit olduğu "Basit Rastgele Örnekleme Yöntemi” uygulanmıştır.

$$
\mathrm{n}=\frac{Z^{2} \cdot N \cdot P \cdot Q}{N \cdot D^{2}+Z^{2} \cdot P \cdot Q}
$$

n: Örnek büyüklüğü,

Z: Güven katsayısı (\%95'lik için bu katsayı 1,96 alınmaktadır.) 
N: Ana kütle büyüklüğü

P: Ölçmek istediğimiz özelliğin ana kütlede bulunma ihtimali (\%50 alınacak)

$\mathrm{Q}=1-\mathrm{P}$

$\mathrm{D}$ : Kabul edilen örnekleme hatası $(\mathrm{Bu}$ makalede \%5'lik bir örnekleme hatası öngörülmüştür), (Özdamar, 2001).

Trabzon Orman Bölge Müdürlüğü orman köylerinde ORKÖY kredisi ile desteklenmeyen 1516, desteklenen 421, olmak üzere toplamda da 1937 ailenin olduğu tespit edilmiştir.

ORKÖY Fenni Arıcılık kredisi ile desteklenmeyen işletmeler için örnek büyüklüğü 306 adet, desteklenen işletmelerin örneklem büyüklüğü 201 adet olarak tespit edilmiştir (Tablo 1).

Tablo 1. Örneklem büyüklüğ̈̈ Table 1. Sample size

\begin{tabular}{ccccccc}
\hline & \multicolumn{3}{c}{ ORKÖY } & \multicolumn{3}{c}{ ORKÖY } \\
Grup & \multicolumn{2}{c}{$\begin{array}{c}\text { Fenni Arıc1lk } \\
\text { Desteklenmeyen }\end{array}$} & \multicolumn{3}{c}{$\begin{array}{c}\text { Fenni Arıc1lik } \\
\text { Desteklenen }\end{array}$} \\
& Ar1c1 & Ort. & Anket & Arrc1 & Ort. & Anket \\
\hline $1-20$ & 239 & 15,7 & 49 & 31 & 7,3 & 14 \\
$21-40$ & 332 & 21,9 & 67 & 192 & 45,6 & 92 \\
$41 \leq+$ & 945 & 62,3 & 190 & 198 & 47,4 & 95 \\
Top. & 1516 & 100 & 306 & 421 & 100 & 201 \\
\hline
\end{tabular}

Örneklem büyüklüğüne göre arıcılık işi ile uğraşanların sayısı fazla olduğundan ve 1., 2., ve 3. gruba kaç adet anket uygulanacağının belirlenmesi için "Tabakalı Tesadüfü Örnekleme" yöntemi uygulanmıştır (Daşdemir, 2016).

ORKÖY Fenni Arıcılık kredisi ile desteklenen 1., 2. ve 3. grup için en az 306 adet, desteklenmeyen gruplar içinde en az 201 adet olmak üzere toplamda 507 anket yapılması gerektiği hesaplanmıştır.

Çalışmadaki özgün alan verilerimizi; çalışma alanındaki ORKÖY kredisi ile desteklenen ve desteklenmeyen arı ve ürünleri üreten işletme sahipleriyle kapalı uçlu sorulardan oluşan anket formuyla yüz yüze anket uygulaması sonucunda elde edilmiştir.

\section{Bulgular}

\subsection{Arıcıların güncel durumu}

Anket yapılan 523 arıcıdan sadece 1 kişi kadın olup, \%94,9'unun evli, \%72,1'i nin 50 yaş ve üzerinde, \%51,1'inin de ilkokul mezunu olma oranlarının en yüksek olduğu görülmüştür. Arıcıların \%91,8'inin köyde, \%6,7'sinin ilçede ve \%1,5'inin de ilde ikamet ettiği görülmektedir.
Tablo 2. Arıcıların güncel durumu

Table 2. Current status of beekeepers

\begin{tabular}{|c|c|c|}
\hline Güncel Durum & & Oran $\%$ \\
\hline \multirow{2}{*}{ Cinsiyet } & Erkek & 99,9 \\
\hline & Kadin & 0,1 \\
\hline \multirow{5}{*}{ Yaş } & +-29 & 1,7 \\
\hline & $30-39$ & 6,3 \\
\hline & $40-49$ & 19,9 \\
\hline & $50-59$ & 36,9 \\
\hline & $60-+$ & 35,2 \\
\hline \multirow{5}{*}{ Eğitim Seviyesi } & Okur-Yazar & 1,9 \\
\hline & İlkokul & 51,1 \\
\hline & Ortaokul & 12 \\
\hline & Lise & 22,8 \\
\hline & Üniversite & 12,2 \\
\hline \multirow{6}{*}{$\begin{array}{l}\text { Arıcılık Dışındaki } \\
\text { Geçim Kaynağı }\end{array}$} & Sadece arıcılik & 5,4 \\
\hline & Emekli & 28,9 \\
\hline & Hayvanc1lık & 5,9 \\
\hline & Bitkisel üretim & 6,1 \\
\hline & 2 farklı iş & 33,1 \\
\hline & 3 farklı iş & 3,3 \\
\hline \multirow{2}{*}{$\begin{array}{l}\text { Aileden İşgücü } \\
\text { Yardımı Alma }\end{array}$} & Aliyor & 35,4 \\
\hline & Almiyor & 64,6 \\
\hline \multirow{3}{*}{ İkamet Durumları } & Köy & 91,8 \\
\hline & İlçe & 6,7 \\
\hline & İl & 1,5 \\
\hline \multirow{2}{*}{$\begin{array}{l}\text { Sosyal Güvence } \\
\text { Durumu }\end{array}$} & Var & 88,7 \\
\hline & Yok & 11,3 \\
\hline \multirow{4}{*}{$\begin{array}{l}\text { Arıcılık Dışındaki } \\
\text { Aylık Gelir Durumu }\end{array}$} & $1-1000 \mathrm{TL}$ & 11,3 \\
\hline & $1001-2000 \mathrm{TL}$ & 53,2 \\
\hline & 2001-3000 TL & 14,3 \\
\hline & $3001-+\mathrm{TL}$ & 3,1 \\
\hline \multirow{6}{*}{$\begin{array}{l}\text { Arıcılık Dışındaki } \\
\text { Yıllık Gelir Durumu }\end{array}$} & Geliri olmayan & 41,7 \\
\hline & $1-5000 \mathrm{TL}$ & 18 \\
\hline & $5001-10000 \mathrm{TL}$ & 14,9 \\
\hline & $10000-15000 \mathrm{TL}$ & 10,3 \\
\hline & $15001-20000 \mathrm{TL}$ & 5,5 \\
\hline & $20000-+\mathrm{TL}$ & 9,6 \\
\hline \multirow{6}{*}{$\begin{array}{l}\text { Arıcılığa Başlama } \\
\text { Nedenleri }\end{array}$} & Baba Mesleği & 46,5 \\
\hline & Arıcılık Kursu & 11,1 \\
\hline & Hobi olarak & 20,5 \\
\hline & Merak ettim & 10,5 \\
\hline & Akraba ve Çevre & 8,6 \\
\hline & ORKÖY & 2,8 \\
\hline \multirow{4}{*}{$\begin{array}{l}\text { Arıcılık Mesleğiyle } \\
\text { Uğraşma Süresi }\end{array}$} & $0-10$ & 25,4 \\
\hline & $11-20$ & 29,6 \\
\hline & $21-30$ & 20,4 \\
\hline & $31-+$ & 29,4 \\
\hline \multirow{2}{*}{$\begin{array}{l}\text { Arıcılar Birliğine Üye } \\
\text { Olma Durumu }\end{array}$} & Üye & 71,7 \\
\hline & Üye Değil & 28,3 \\
\hline \multirow{2}{*}{ Gezginci Arıc1 } & Trabzon & 85,4 \\
\hline & Rize & 68,6 \\
\hline \multirow{2}{*}{ Sabit Arıc1 } & Gümüşhane & 88,5 \\
\hline & Bayburt & 52,6 \\
\hline
\end{tabular}


Arıcıların, arıcılık dışındaki geçim kaynaklarına bakıldığında emekli olanların oranının \%28,9 olduğu, \%64,6'sının aileden işgücü yardımı almadan faaliyetlerini yürüttüğü, arıcılık dışında aylık gelir oranının 1001-2000 TL arasında, yıllık gelir durumları oranının da 5001-10000 TL arasında en yüksek oranda olduğu tespit edilmiştir.

Arıcıların \%46,5'i bu işi baba mesleği olduğundan yürütmekte, \%29,6 sı da arıcılık işiyle 11-20 yıldır uğraşmakta olduğu belirlenmiştir. \%71,7'si Arıc1lar Birliğine üyedir.

Trabzon $(\% 85,4)$ ve Rize $(\% 68,6)$ ilinin gezginci arıcılık yaptığ 1 , Gümüşhane $(\% 88,5)$ ve Bayburt $(52,6)$ ilinin de sabit arıcılık yaptıkları belirlenmiştir (Tablo 2).

Arıcılık faaliyetlerini gerçekleştirirken \%49'unun arı beslenme (şeker, arı keki, çeşitli ballar), \%23'ünün kovan talebi, \%23,3'ünün de temel petek talebi olduğu tespit edilmiştir.

Arıcıların 174 adet barakaya, 258 adet otomatik bal süzme makinesine, 179 adet dinlendirme kazanına ve 40 adet diğer (karavan, güneş enerjisi paneli, ayı tuzağ 1 , polen kurutma firını) talepleri bulunduğu görülmektedir (Tablo 3).

Tablo 3. Arıcıların donanım eksikliği

Table 3. Lack of quipment of beekeepers

\begin{tabular}{lcc}
\hline Donanım Çeşidi & Talep & Oran \% \\
\hline Baraka & 174 & 26,7 \\
Otomatik Bal Süzme Mak. & 258 & 39,6 \\
Dinlendirme Kazanı & 179 & 27,5 \\
Diğer & 40 & 6,2 \\
\hline
\end{tabular}

Arı işletmelerinin \%55,3'ünün arıcılık faaliyetlerinin herhangi bir döneminde arıcılık kredisi kullanmış olduğu görülmektedir. Arıcılık kredisi kullanan 289 adet işletmenin \%67,8'inin ORKÖY'den, \%28'inin Ziraat Bankasından kredi kullandıkları belirlenmiştir.

Bu kredilerin \%2,1'ini ana arı temininde, \%75,1'ini arı ailesi ve kovan temininde (ORKÖY kredi şekli), $\% 9,3$ 'ünü arıcılık faaliyetleri girdilerinde (temel petek, beslenme ve kovan aparatları gideri) kullanıldığ 1 belirlenmiştir. Orman köylerinde kredi kullanan 289 adet işletmecinin \%51,9'u kullandıkları kredinin beklentilerini karşıladığ $1, \% 48$, 1'inin beklentilerini karşılamadığı görülmektedir.

\subsection{Arı hastalıkları ve kayıpları}

Çalışma alanında \%58,9 oranında ana arı problemi olduğu görülmektedir. Arıcıların \%51,8 oğulu, suni yolla üretmektedir. Oğul satış durumu incelendiğinde, sadece \%15,3’ü oğul satışı yaparken, \%84,7'sinin de oğulu işletmenin devamını sağlamak için kullandıkları görülmektedir.

Arıcıların \%84,9'unun arı sağlığıyla ilgili gerekli bilgiye sahip oldukları $\% 15,1$ 'i ise bilgi sahibi olmadıkları görülmüştür. Arılıklarda Varroa hastalığı \%34,2 iken Varroa ve yavru çürüklüğ̈̈ hastalığının bir arada bulunma durumu \%35,6 oranındadır.

Tablo 4. Arı hastalıkları ve kayıları Table 4. Bee diseases and losses

\begin{tabular}{|c|c|c|}
\hline Durum & & Oran \% \\
\hline \multirow{4}{*}{$\begin{array}{l}\text { Arılıklarda } \\
\text { Karşılaşılan } \\
\text { Hastalık Durumu }\end{array}$} & Varroa & 51,6 \\
\hline & Yavru çürük & 4,6 \\
\hline & Varroa + yavru ç. & 35,6 \\
\hline & Diğer & 8,2 \\
\hline \multirow{8}{*}{$\begin{array}{l}\text { Hastalıklarla } \\
\text { Mücadelede Yardım } \\
\text { Alma Durumu }\end{array}$} & Kendi bilgilerine & 13,4 \\
\hline & Özel veteriner & 3,8 \\
\hline & Tarım veteriner & 12,4 \\
\hline & Tecrübeli arıcı & 23,1 \\
\hline & (Kendi bilgi + & 24 \\
\hline & Tecrübeli arıcı) & 24 \\
\hline & $\begin{array}{l}\text { (Tarım veteriner }+ \\
\text { Tecrübeli arıcı) }\end{array}$ & 8,8 \\
\hline & Diğer & 14,5 \\
\hline \multirow{3}{*}{$\begin{array}{l}\text { K1şlatma } \\
\text { Hazırlığ1 }\end{array}$} & Yapan & 94,1 \\
\hline & Yapmayan & 5,9 \\
\hline & Trabzon & 16,5 \\
\hline \multirow{3}{*}{$\begin{array}{l}\text { Kişlatmada } \\
\text { Koloni Ölüm Durumu }\end{array}$} & Rize & 27,9 \\
\hline & Gümüşhane & 31,9 \\
\hline & Bayburt & 15,6 \\
\hline \multirow{6}{*}{$\begin{array}{l}\text { Kışlatma } \\
\text { Kayıpları Nedenleri }\end{array}$} & Varroa & 29,5 \\
\hline & Ana kaybı & 16,1 \\
\hline & Yağmacilık & 4,1 \\
\hline & Açlik & 7,5 \\
\hline & Varro +ana kaybı & 18,1 \\
\hline & Çoklu nedenler & 24,7 \\
\hline \multirow{9}{*}{$\begin{array}{l}\text { Yaban } \\
\text { Hayvanlarından Zarar } \\
\text { Görme Durumu }\end{array}$} & Zarar yok & 7,1 \\
\hline & Ay1 & 5,4 \\
\hline & Kirpi & 1,5 \\
\hline & Eşek arısı & 4 \\
\hline & Kuş & 2,9 \\
\hline & Kurbağa & 0,2 \\
\hline & Ay1+kuş & 7,8 \\
\hline & Ay1+eşek arıs1 & 8 \\
\hline & Çoklu nedenler & 17,1 \\
\hline
\end{tabular}

Ar1 hastalıklarıyla mücadelede arıc1ların \%13,4'ü kendi bilgilerine güvenirken, \%23,1'i tecrübeli ar1cılardan yardım almaktadır. Arıcıların \%94,1'inin kışlatma hazırlıklarını yapmasına rağmen, kışlatmada koloni ölüm oranları, \%31,9 ile Gümüşhane ilinde ve ardından \%27,9 ile de Rize ilindedir.

Arılıkların \%51,4'ü en çok ayıdan zarar görmüştür. Kışlatma kayıplarının başında \%29,5 ile Var- 
roa hastalığg1, \%16,1 ile ana kaybı ve diğer nedenler gelmektedir.

Arıcıların ayıdan zarar görme durumu Trabzon ilinde $\% 40,5$, Rize ilinde $\% 66,7$, Gümüşhane ilinde $\% 67,3$ ve Bayburt ilinde $\% 44,7$ oranında olduğu görülmüştür. Arı işletmelerinin \%60'ında da yaban hayvanlarından korunmak için ekipman olmadığ tespit edilmiştir. Yaban hayvanlarından zarar görmeyenlerin oran 1 sadece $\% 7,1$ dir (Tablo 4).

\subsection{Arı nakli ve konaklama yeri durumu}

Ankete katılan arıciların 367'si gezginci arıc1 olup, bunların \%81,5'inin arılarını nakil sırasında sigorta yaptırmadıkları belirlenmiştir. Arıcıların \%62,1'i arılarının naklini ücret karşılığında yaptırmaktadır. Konaklama yeri temininde en çok zorlanan il \%53,6 ile Trabzon olurken, sabit arıcılığın yoğun olduğu Gümüşhane ilinde bu oran \%7,7 dir. Arıcıların \%44'ü konaklama yerini pahalı bulmaktadir. Arı konaklama yerlerinin \%50,9'unda elektrik, \%73,8'inde temiz su bulunmaktadır (Tablo 5).

Tablo 5. Ar1 konaklama yerinin durumu

Table 5. Conditions of bee accommodation

\begin{tabular}{|c|c|c|}
\hline Durum & & Oran \% \\
\hline \multirow{4}{*}{$\begin{array}{l}\text { Konaklama yeri temin } \\
\text { zorluğu durumu yeri }\end{array}$} & Trabzon & 53,6 \\
\hline & Rize & 27,7 \\
\hline & Gümüşhane & 7,7 \\
\hline & Bayburt & 36,8 \\
\hline \multirow{2}{*}{$\begin{array}{l}\text { Konaklama yeri pahalı } \\
\text { mı? }\end{array}$} & Evet & 44 \\
\hline & Hayır & 56 \\
\hline \multirow{2}{*}{$\begin{array}{l}\text { Konaklama yerinde su } \\
\text { var mi? }\end{array}$} & Evet & 73,8 \\
\hline & Hayır & 26,2 \\
\hline \multirow{2}{*}{$\begin{array}{l}\text { Konaklama yerinde } \\
\text { elektrik var mi? }\end{array}$} & Evet & 50,9 \\
\hline & Hayır & 49,1 \\
\hline \multirow{2}{*}{$\begin{array}{l}\text { Konaklama yeri güvenli } \\
\text { mi? }\end{array}$} & Evet & 74,7 \\
\hline & Hayır & 25,6 \\
\hline \multirow{2}{*}{$\begin{array}{l}\text { Konaklama yeri köye } \\
\text { anayola yakın mi? }\end{array}$} & Evet & 59,8 \\
\hline & Hayır & 40,2 \\
\hline \multirow{2}{*}{$\begin{array}{l}\text { Konaklama yerinde } \\
\text { tarım ilacı kullanımı }\end{array}$} & Evet & 22 \\
\hline & Hayır & 78 \\
\hline \multirow{2}{*}{$\begin{array}{l}\text { Tarım ilacından koloni } \\
\text { ölme durumu }\end{array}$} & Evet & 50,4 \\
\hline & Hayır & 49,6 \\
\hline \multirow{2}{*}{$\begin{array}{l}\text { İlaçlama Tarım } \\
\text { İl Müdürlüğünün } \\
\text { belirlediği günlerde mi } \\
\text { yapılıyor? }\end{array}$} & Evet & 15,7 \\
\hline & Hayır & 84,3 \\
\hline \multirow{2}{*}{$\begin{array}{l}\text { Arıcılar ballı bitkileri } \\
\text { tanıyor mu? }\end{array}$} & Evet & 93,9 \\
\hline & Hayır & 6,1 \\
\hline \multirow{4}{*}{$\begin{array}{l}\text { Yörenizde bal ormanı } \\
\text { bulunma durumu }\end{array}$} & Trabzon & 11,3 \\
\hline & Rize & 22,6 \\
\hline & Gümüşhane & 48,1 \\
\hline & Bayburt & 0 \\
\hline \multirow{2}{*}{ Bal ormanlar1 yeterli mi? } & Evet & 10,9 \\
\hline & Hayır & 89,1 \\
\hline
\end{tabular}

Arıcıların \%22'sinin konaklama yerinin etrafinda tarım ilacı kullanılmaktadır. Arı işletmelerinin \%50,4'ünde de tarım ilacı kullanılmasından kaynaklanan koloni ölümlerinin olduğu görülmektedir. Arıcıların \%89,1'i Bal ormanlarını yeterli bulmamaktadır.

\subsection{Arıcılık eğitimi}

Arıcıların \%92'si hayatlarının bir döneminde arıcılık konusunda eğitim aldıkları ve bunların \%89,5'inin de arıcılık sertifikası olduğu belirlenmiştir Arıcıların \%83,2'si arıcılık faaliyetleri için daha fazla bilgi talep ederken, \%16,8'i şu anlık bilgilerinin yeterli olduğunu beyan etmişlerdir. Arıcıların \%70,4'ü arıcılık konusunda karşılaştıkları sorunları ve merak ettiği konuları araştırırken, \%29,6'lık kısmı arıcılık konusunda araştırma yapmadıklarını belirtmiştir. Bilgiye ihtiyaç duyulan konular durumunda, Trabzon ilinde \%56,7 ve Rize ilinde \%64,7 ile "arı hastalıkları ve ilaç kullanımı" konularında bilgi sahibi olmak istemektedirler. Gümüşhane ilinde \%36,6 ve Bayburt ilinde \%53 ile de "genel arıcılık" konularında bilgi sahibi olmayı talep etmektedirler.

Arıcıların \%43'ü arıcılık konusunda internet kullanırken, \%57'si kullanmamaktadır (Tablo 6).

Tablo 6. Arıcılık eğitimi

Table 6. Beekeeping education

\begin{tabular}{llc}
\hline Durum & & $\begin{array}{c}\text { Oran } \\
\%\end{array}$ \\
\hline Arıcılık konusunda eğitim & Evet & 92 \\
görme & Hayır & 8 \\
\hline Arıcılık sertifikası sa- & Evet & 89,5 \\
hiplik & Hayır & 10,5 \\
\hline Arıcılık faaliyetlerinde & Evet & 83,2 \\
bilgi isteme durumu & Hayır & 16,8 \\
\hline Arıcılıkla ilgili araştırma & Evet & 70,4 \\
yapma durumu & Hayır & 29,6 \\
\hline & Genel arıcılık & 23,9 \\
& Ana arı ve arı & 12,4 \\
Eğitim talep edilen ko- & ürünleri üretimi & \\
nular & Arı hastalıkları & 53,1 \\
& ve ilaç kullanımı & \\
& Verimli ve teknik & 10,6 \\
\hline Arıcılık konusunda inter- & Evet & 43 \\
net kullanımı & Hayır & 57 \\
\hline
\end{tabular}

\subsection{Arı ürünlerini pazarlama durumu}

Ballarda kalıntı analizi yaptırmayanların oranı $\% 75,9$ olup, kalıntı analizi yaptıran 126 arıcının \%23'ünün Hacettepe Üniversitesinde, \%21,5'inin de Rize Arıcılar Birliği aracılığıyla analizlerini 
yaptırdığı belirlenmiştir. Arı ürünlerinden \%59,7 ile sadece süzme bal, \%21,2 ile de süzme ve petek bal bir arada pazarlanmaktadir.

Ürünlerin pazarlamasında \%93,5 oranında "perakende olarak tanıdıklarıma pazarlıyorum" pazarlama çeşidi kullanılmaktadır. Pazarlamada karşılaşılan sorunlara baktığımızda \%25,4'ünün pazarlama sorunu olmadıkları, \%13,4'ünün de pazara dişarıdan kontrolsüz ürün girmesi problemi yaşadıkları görülmüştür (Tablo 7).

Tablo 7. Arı ürünleri pazarlama durumu

Table 7. Marketing situations of bee products

\begin{tabular}{|c|c|c|}
\hline Durum & & Oran $\%$ \\
\hline \multirow{2}{*}{$\begin{array}{l}\text { Ballarda Kalıntı Analizi } \\
\text { Yaptırma Durumu }\end{array}$} & Yaptiran & 24,1 \\
\hline & Yaptırmayan & 75,9 \\
\hline \multirow{7}{*}{ Pazarlanan Arı Ürünleri } & Süzme bal & 59,7 \\
\hline & Petek bal & 1,7 \\
\hline & Süzme bal+petek bal & 21,2 \\
\hline & Süzme bal+oğul & 5,9 \\
\hline & Süzme bal+polen & 3,5 \\
\hline & (Süzme bal+Petek bal+polen) & 3,6 \\
\hline & Diğer & 4,4 \\
\hline \multirow{4}{*}{ Ürün Pazarlama Türü } & Perakende olarak tanıdıklarıma pazarlıyorum & 93,5 \\
\hline & Perakende olarak pazarda pazarlıyorum & 1 \\
\hline & Yerel toptancilara pazarliyorum & 1,7 \\
\hline & Ar1 Yetiştiricileri Birliği aracılığıyla pazarlıyorum & 3,8 \\
\hline \multirow{9}{*}{$\begin{array}{l}\text { Pazarlamada Karşılaşılan } \\
\text { Sorunlar }\end{array}$} & 1-Sorunu olmayan & 25,4 \\
\hline & 2-Pazara dışarıdan kontrolsüz ürün girmesi & 13,4 \\
\hline & 3-Ürünlerin hak ettiği değerin altında satılması & 4,6 \\
\hline & 4-Tüketicinin arı ürünlerinin doğallığından şüphe duyması & 0,4 \\
\hline & 5-Pazarlamada birlik veya kooperatiflerin olmaması & 4 \\
\hline & $\begin{array}{l}\text { 2-Pazara dişarıdan kontrolsüz ürün girmesi } \\
\text { 3-Ürünlerin hak ettiği değerin altında satılması } \\
\text { 4-Tüketicinin arı ürünlerinin doğallığından şüphe duyması } \\
\text { 5-Pazarlamada birlik veya kooperatiflerin olmaması }\end{array}$ & 14,5 \\
\hline & $\begin{array}{l}\text { 2-Pazara dişarıdan kontrolsüz ürün girmesi } \\
\text { 5-Pazarlamada birlik veya kooperatiflerin olmaması }\end{array}$ & 10,3 \\
\hline & $\begin{array}{l}\text { 2-Pazara dışarıdan kontrolsüz ürün girmesi } \\
\text { 3-Ürünlerin hak ettiği değerin altında satılması }\end{array}$ & 7,5 \\
\hline & Karma & 19,9 \\
\hline
\end{tabular}

\section{Tartışma Sonuç ve Öneriler}

Trabzon Orman Bölge Müdürlüğü orman köylerindeki arıcıların \%99,9 unun erkek olduğu belirlenmiştir. Arıcıların \%72,1'i 50 yaşın üzerinde olup, \%5,4'ününde tek geçim kaynağı arıcılıktır. \%96,4'ü ise arıcılığı ek gelir sağlamak amaciyla yapmaktadır. Arıcıların \%28,9'u emekli iken, \%33,1'i de arıcılık dışında 2 adet işle uğraşmaktadır. Arıcıların çoğunluğu emekli olduğundan, arıcılık dışında fındık, çay tarla sebzeciliği, hayvancılık ve işçilik gibi geçim kaynakları bulunmaktadır. Tunca ve Çimrin, (2012)'deki çalışmasıyla benzelik göstermektedir.
Arıcılığın tek geçim kaynağı olacak duruma getirilmesi için arıcılık faaliyetlerine daha fazla önem verilmelidir. Arıcıların \%8'i 40 yaşın altında olup, \%3,8' i bekardır. ORKÖY kredileri bekarlara verilmediğinden gençler bu işe erken yaşta başlayamamakta ve arıclığı bir meslek olarak tercih etmemektedirler. ORKÖY ve diğer kurumlar tarafından gençler desteklenmeli, arıcılık özendirilmeli ve arıcılık eğitimi üniversitelerin eğitim programalarına koyulmalıdır.

Arıcıların \%91,8'i köyde ikamet ettiğinden ORKÖY kredilerinden faydalanma şartlarınıda sağlamaktadırlar. \%1,9'unun okur-yazar ve \%51'inin 
ilkokul mezunu olma durumu arıcilara verilecek eğitim programları açısından önemli bir göstergedir. Lise ve üniversite mezunlarının oranının \%35 olması ise arıcılık alanındaki yeni teknolojileri ve yayınları yakından takip ettiklerini göstermektedir. Araştırmamız ile Soysal ve Gürcan (2005)'ın çalışması arasında da benzerlik görülmüştür.

Orman köylerindeki arıcıların \%35,4'ü arıcılık faaliyetlerini yürütebilmesi için \%55'i eşlerinden, \%20'si çocuklarından işgücü yardımı almaktadır. Aile bireyleri hayvancılık, bitkisel üretim ve diğer geçim kaynakları ile ilgilenmekte olup Erkan ve Aşkın, (2001)'ın bulgularıyla benzerdir.

İşletme sahiplerinin arıcılık dışındaki aylık gelir durumları incelendiğinde \%18,2'sinin düzenli olarak aylık gelirinin olmadığ 1 ve \%53,2'sininde 1001-2000 TL aralığında emekli veya asgari ücretle maaşları olduğu görülmüştür. Bölüktepe ve Yılmaz, (2008)'ın çalışmasında da benzer durum görülmüştür. Trabzon'da fındık tarımı, Rize'de çay tarımı, Gümüşhane ve Bayburt illerinde hububat yetiştiriciliği yem bitkisi tarımı ve hayvancılık yapılmasına ragmen, işletmelerin \%41,7'sinin

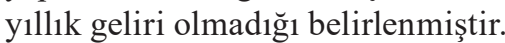

Arıcıların; \%46,5'i baba mesleği olduğundan, $\% 31$ 'i hobi ve merak olarak \%11,1'i arıc1lk kursu sayesinde ve \%2,8'inin ORKÖY destekleri sayesinde mesleğe başlasalar da Orman köylerinde yeni projelerin uygulanması oldukça zordur. Hobi ve merak olarak arıcılığa başlayanlar koloni kayıpları fazla olduğunda veya arı ürünleri üretimi az olduğunda arıcılığı bırakmaktadırlar. Araştırmamızda, Yaşar ve ark., (2002)'nın çalıșmasıyla benzer olarak, arıcıların yaklașık \%50'si 20 yıldan fazla bu meslekle uğraşmaktadır.

Arıcıların \%28,3'ünün kendi ilindeki Ar1 Yetiştiricileri Birliğine veya Türkiye Bal Üreticileri Merkez Birliğine üye olmadıkları belirlenmiştir. Türkiye Arıcılar Birliği ve Bal Üreticileri Birliğinden herhangi birisine üye olan üreticilere 2017 yılında ana arı desteği olarak 15 TL, arılı kovan desteği olarak 10 TL ve damızlık ana arı desteği olarak 40 TL verilmiştir (URL 6, 2017). Birlik üyesi olmayan arıcılar hem bu desteklerden hem de illerdeki Arı Yetiştiricileri Birliklerinin üyeleri için düzenlemiş olduğu diğer faaliyetlerden faydalanamamaktadir.

Sonbahar ve erken ilkbahar kovan bakımlarında arıları güçlendirmek için beslenme gideri desteğine ihtiyaç bulunmaktadır. Orman Köylülerinin Desteklenmelerine ait 7022 Nolu tamim gereğince, ORKÖY' ün Fenni Arıcılık kredi desteklerinde
Tip Proje olarak sadece 30 adet arılı kovan desteği verilmektedir. Arıcıların kovanları ahşaptan yapılmış langstroth tipi kovanlar olduğundan eskiyen kovanlarının yerine yenilerini talep etmektedirler. Arıcılar \%100 saf balmumundan üretilmiş hazır temel petekler kullanmaktadırlar. Ancak kullanamayacakları temel peteklerini, petek işleme tesislerinde 1 atmosfer basinçta $120^{\circ} \mathrm{C}$ 'de 15 dakika süreyle sterilizasyon işlemine tabi tutturarak temel peteklerini üretim maliyetine yaptırılmaktadır. Balı süzülen peteklerde mum güvesine (Galleria mellonella) karşı uygun koşullarda saklanmalıdır (URL 7, 2017). Bu doğrultuda arıcılık faaliyetlerinde beslenme, kovan ve temel petek ihtiyacı talepleri dikkate alınarak ORKÖY fenni arıcılık kredi destekleri çeşitlendirilmelidir.

Arıcıların \%55,3'ü arıcılık faaliyetlerinin herhangi bir döneminde arıcılık kredisi kullanmış olduklarını belirtmişlerdir. Kredi türleri açısından baktığımızda arıcıların \%67,8'i ORKÖY tarafindan fenni arıcılık (30 arılı kovan) kredisi ile desteklenmiş, \%28'i Ziraat Bankasından kredi kullanmıştır. Kredilerden arıcıların kolaylıkla faydalanabilmesi bir firsat olarak düşünülmektedir. Orman köylerinde kredi kullanan 289 adet işletmecinin \%51,9’u kullandıkları kredinin yeterli olmadığı kaanatindedir.

Arıcılar \%58,9 oranında olan ana arı problemini, ana arıyı dışarıdan temin ederek gidermektedirler. \%41,1 oranında ana ar1 problemi olmayanlar da ana arıyı doğal yolla kendileri üretmektedirler. Araştırmamız, Kekeçoğlu ve ark., (2007), yaptığı çalışma ile de benzerlik göstermiştir. Trabzon OBM alanları için en önemli sorun; ana arı yetiştiriciliğinin sertifikalı olarak yapılmaması ve yöreye uygun saf ırkların bulunmamasıdır. Gezginci arıc1lıktan dolayı da ana arı 1rkı bozulabilir. Ana arı, işletmelerinin ürün verimini ve kolonilerin hastalıklara karşı dirençli olmasıını sağlamaktadır. Genç ana arı daha fazla feromon salgılar, koloniyi daha düzenli sevk ve idare eder, daha fazla ve düzenli yumurtlar ve koloninin daha güçlü işçi arılarının olmasını sağlar. Özellikle gezginci arıcılık yapan işletmeler kolonilerini damızlık ana arıdan üretilmiş genç ana arılarla 2 yılda bir yenilenmelidir. Sertifikalı ve yöresine uygun ana arı üreten işletmeler desteklenerek sayıları arttırılmalıdır. Güçlü koloniler bölünerek yada çekirdek koloni oluşturarak çoğaltılmalıdır (Güler, 2017).

İşletmelerin sadece \%15,3'ü oğul satış1 yapmaktadır. Ar1 ürünü olan oğuldan elde edilen kolonilerin satışı arcılık için önemli ve karlı bir gelir kaynağıdır. \%84,7'si de oğul satışı yapmayarak işletmelerin kapasite kullanımı yönünden devamlılığını sağlamaktadır. Arıcıların \%51,8'i 
sadece suni yöntemler ile kolonileri çoğaltmaktadır.

Arıcıların \%84,9’u arı sağlı̆̆ıyla ilgili gerekli bilgiye sahip olduklarını belirtmişlerdir. Arılıklarda $\% 51,6$ oranında Varroa, \%4,6 oranında yavru çürüklüğü, \%35,6 oranında Varroa ve yavru çürüklüğünü bir arada gördüklerini belirtmişlerdir. Uygun olmayan çevre koşulları, arı ırkının sahip olduğu genetik üstünlüğü ortaya koymasına izin vermediği gibi sağlıklı olmasına da izin vermez. Koloni strese girer, direnç gücü zayıflar ve hastalıklar baş gösterir. Arıların uçuş davranışlı canlılar olması, bölgeler ve arılıklar arasında yoğun arı hareketliliği, hastalıklı kolonilerden sağlıklı kolonilere arı, yavru ve petek aktarımı, akar ile bulaşık arıların kovanlarını şaşırarak diğer kolonilere girmesi, doğal oğul, arılık içerisinde yağmacılık oluşması, açıkta besleme, yanlış mücadele yöntemlerinin uygulanması, göçer arıcılık uygulamaları, yetiştiricilerin hastalık konusundaki bilgilerinin yetersiz oluşu, toplu mücadelenin uygulanmayışı, çoğu insan müdahalesi olmak üzere doğada yaratılan biyolojik dengesizlikten dolayı hastalıklar yayılmaktadır (Güler, 2017). Şeker ve ark., (2017)'nın, Malatya'daki çalışmalarında da en en fazla görülen arı hastalığının Varrosis \% 47,8 ve yavru çürüklüğü \%32,2 olduğu görülmektedir.

Arıcılar hastalıklarla mücadelede ilaç kullanırken, $\% 13,4$ 'ü sadece kendi bilgilerine göre, \%23,'ü ise Arıcılar Birliği üyeliklerinden iletişimlerinin güçlü olmasından dolayı önce birbirlerine daha sonrada Tarım İl Müdürlüğü veterinerine danışmaktadırlar. Kullanacakları ilaçlar konusunda uzmanlara değilde kendi tutumlarına göre davrandıklarıgörülmüştür. İthal ve yerli RULAMİT VA, VAMITRAT-VA, VARROSTOP, BYVAROL, APIVAR, APISTAN \%10, FORMISET ilaçlar kullanmaktadırlar. Arı hastalıklarına karşı topluca ilaçlama yapılamadığından dolayı hastalıklarla mücadelede bilinçsizce de ilaç kullanılmaktadır.

Varroa ve diğer hastalıklarla mücadele zamanında ve uygun ilaçlarla önce yöresel, sonra da bölgesel ilaçlama yapılmalıdır. Arı hastalıklarında insan sağlığına zarar verecek ruhsatsız ilaçların kullanılmaması için arıcılar sıkı denetlenmeli ve sonucunda sert yaptırımlar uygulanmalıdır. Özellikle temel petek üzerinde ilaç kalıntılarının ve pestisitlerin kalmaması için temel petek üretim tesisleri s1k1 denetlenmeli ve üretim standardına uymayanlara cezai yaptırımlar uygulanmalıdır. Arı ve arı ürünlerinin üretiminde çevre koşulları iyi oluşturulmalı, sağlıklı girdiler kullanılmalı ve girdilere de standart getirilmelidir.

Arıcıların \%94,1’i kışlatma hazırlıklarını yeterince yaptıklarını belirtmelerine rağmen yinede $\% 84,3$ oranındaki işletmede koloni ölümleri olmaktadır. Genç analar kışın daha az ölüm riski taşıdıklarından ve daha iyi kuluçka yaptıklarından anas1 genç koloniler kışı daha garantili geçirirler (Doğaroğlu ve Doğaroğlu, 2015). Kış mevsiminde kovan kapakları açılmaz ve koloniye herhangi bir şekilde müdahale edilmez. Bu yüzden kolonilere sonbahar bakımında yer düzenlemesi yapılır. Zayıf koloniler birleştirilerek güçlendirilir. Kış mevsimi boyunca ihtiyaçlarını karşılayacak miktarda bal birakılır. Hastalık ve parazitlerle mücadele edilir. Kovanın çatlakları tamir edilir ve uçuş delikleri kapatılır. Kolonideki nem birikimini önleyecek her türlü uygulamadan kaçınılır (Güler, 2017). Sonbahar bakımında arının polenle beslenerek vücutlarında bulunan vitellogenin oranını arttırılması sağlanmalıdır. Vitellogenin (Glikoz $(\% 2)+$ Lipo (\% 6) + Protein (\%91)) arıların karın kısmında bulunur, arının yağıdır. Vitellogenin arıların kışlamasında ve sağlıklı kalmasında çok önemlidir. Aç kaldıklarında bu yağı kullanırlar hatta bu yağı arı sütüne çevirerek yavru da besleyebilirler. Vitellogenin azaldığında arının ömrü kısalır, kıştan sağ çıkması zor olur (Anonim 3, 2017).

Türkiye'de 2016-2017 sezonunda gözlenen bal arısı kış koloni kayıpları \%41,2 oranında olmuştur. Bunların \%19,6'sı hastalıklar, \%9,3'ü pestisitler, \%5,6'sı iklim kayıplarından, \%6,7'si ana ar1 ve besleme kayıplarından oluşmuştur (Özkirim, 2017). Araştırmamızda ise koloni ölümlerinin yaşandığ 1 illere baktığımızda, Gümüşhane ilinde \%31,1, Rize ilinde $\% 27,9$, Trabzon ilinde \%16,5 ve Bayburt ilinde $\% 15,6$ oranında koloni ölümleri olduğu tespit edilmiştir. Kışlatma döneminde yaşanan kayıplardan dolayı işletmeler fazla oranda zarara uğramaktadırlar. Kayıpların işletmelere zarar vermesini önlemek için Sonbahar bakımlarını hastalıklarla mücadele ve beslenme bakımından polenli yemleme çok iyi yapılmalıdır. Orköy kredilerini veren Orman İşletme Müdürlüklerince sonbaharda polen veren bitkiler üretilerek, birlikler aracılığıyla arıcılara dağıtımı yapılmalıdır.

Yaban hayvanlarından zarar gören işletmelerin oranı \%92,9 dur. Bunların da \%51,4'ü ayıdan zarar gördüklerini belirtmektedirler ki Kavak ve ark., (2015)'nın çalışmasıyla benzerlik göstermiştir. Arıcıların \%60'ında arılıklarda yaban hayvanlarından korunmak için ekipman bulunmamaktadır. Koloni zaiyatlarının başlıcası arıcılarında belirttiği gibi, arı konaklama yerlerindeki ayı populasyonundan kaynaklanmaktadır. Ayı; arı, larva ve bal yemeyi çok sever bunları yemekle kalmaz bulduğu kovanlarıda parçalayarak işe yaramaz hale getirir. Ayıların avlanması DKMP mevzuatı gereği yasaktır. Fakat arılığa girmesini 
önleyecek tedbirler alınabilir. Ayı başta olmak üzere yabani hayvanlar mevcut arılığa kısmen zarar vereceği gibi tamamen yok olmasına da sebep olmaktadır. ORKÖY tarafından verilen fenni arıcılık kredisinde ayı tuzaklarının verilmesiyle ayı zararları önlenmiş olacaktır.

Gezginci arıcıların \%81,5'i arılarını sigortalamadan nakil yaparken sadece \%18,5 i T.C. Ziraat Bankasından alınan kredi desteği gereği arılarını sigorta yaptırmışlardır. Arı nakliyesi sırasında taşıma araçlarının cezai durumlarından kaynaklanan sorunların çözümü arıların konaklama yerlerine ulaşmalarından sonraya bırakılmalıdır. Seven ve Akkılıç, (2005)'ın çalışmasıyla benzer olarak, araştırmamıza katılan arıcıların \%29,8'i sabit arıcı, \%70,2'side gezginci arıcıdır. Trabzon ilinin \%50,9'u il dışı gezginci, Rize ilinin \%48,6'sı ve Bayburt ilinin \%50'si Bölgeler arası gezginci arıcılık yapmaktadır. Gümüşhane ilinin de $\% 88,5$ 'i sabit arıcıdır. Gezginci arıcıların \%62,1’i de arı nakillerini ücretli yaptırmaktadırlar.

Konaklama yeri temin etmede arıcıların \%40’1 ücretlerini ödedikleri halde zorluk yaşamaktadırlar. Gezginci arıcıların \%44'ü konaklama ücretlerini olduğundan pahalı bulmaktadır. Gezginci arıcıların konaklama yerleri planlanmamış olduğundan dolayı konaklama yeri temininde köy muhtarlarına bağış adı altında keyfi olarak belirlenen miktarlarda para ödemek zorunda kaldıklarını belirtmişlerdir. Tarım ve Orman Bakanlığının ilgili yönetmeliğinde konaklama yerleri için herhangi bir ücret talep edilmemesi konusunda emirleri olmasına rağmen gezginci arıcılar ile yöre halkı arasında maddi ve manevi sorunlar yaşanmaktadır. 2016-2017 yıllarında yaşanan terör olaylarından dolayı arıcıların daha önce gittikleri bölgeler de gidemediklerinden dolayı Gümüşhane, Bayburt ve Erzurum yörelerinde konaklama yerlerinde yı̆̆ılma yaşanmasına neden olmuştur. Gezginci arıcıların konaklama yerleri, arılıklar arası mesafelerin korunması yapılarak planlanmalı ve alt yapıları hazırlanmalıdır.

Tarımsal faaliyetler ve biyoçeşitlilik açısından polinasyon (tozlaşma) önemsenmelidir. Bitkisel üretim yapanlara polinasyonun önemi anlatılmalı, konaklamada sıkıntı yaşanmamalıdır Konaklama yerleri için usulsüz şekilde talep edilen konaklama ücretlerinin alınmaması için gerekli önlemler alınmalıdır. Konaklama yerlerinde baraka, otomatik bal süzme makinesi, dinlendirme kazanı, karavan, tır (kovan yerleştirilmesi düzeneği hazırlanmış), elektrik ihtiyacı için güneş panelleri ve polen kurutma fırını gibi gelişen teknolojiye bağlı ihtiyaçları da karşılanmalıdır. Konaklama yerlerinin \%26,2'inde su bulunmamaktadir. Arılar suya en fazla erken ilkbahar, yazbaşı ve yaz döneminde ihtiyaç duyarlar. Kış sezonunda su ihtiyaçları asgari düzeydedir. Kolonide en fazla su, kovandaki sıcaklık seviyesinin düşürülmesi amacıyla kullanılmaktadır. Arılar $18-30{ }^{\circ} \mathrm{C}$ arasındaki 1lık suyu severler (Güler, 2017). Arılıklarda bulunan sulardan sağlıklı arılar kullandıkları gibi hastalıklı arılar kullandıklarında hastalıklar kolonilere bulaşmaktadır. Ayrıca arıcının hijyen koşularda çalışabilmesi ve günlük su ihtiyacını konaklama yerlerindeki doğal ve temiz su kaynaklarından karşılamaktadır. Araştırmamıza göre arıcıların \%59,8'i köye ve anayola yakın yerlere kovanlarını yerleştirmektedir. Nakliye işlerinin kolay olması, sabit arıcıların güvenlik açısından kovanlarını evlerinin yakınında ve köy içerisinde tutmaları, arıların kirli sulara (deterjan atı̆̆ 1 , bitkisel üretim gübreleri, tarım ilaçlarının atığı) maruz kalmalarından dolayı arı ölümlerine neden olmaktadır. Anayola yakın yerleştirilen kovanların egzoz dumanından ve gürültüden etkilenmesine sebep olmaktadır. Arıcıların \%25,6’sı köy ve diğer yerleşimlere uzak konaklama yerlerinde kendilerini yaban hayvanlarından ve terör olaylarından dolayı güvenli hissetmemektedirler.

Arılıkların \%49,1'inde elektrik bulunmamaktadır. Elektrik, ayı zararlılarıyla mücadelede gece arılık içerisinde 1şık yakılarak tedbir alınmasında, arıların bakım faaliyetlerinde ve arıcıların yaşam standartlarının iyileştirilmesinde zorunlu bir ihtiyaç olarak kullanılmaktadır. Elektrik ihtiyacı güneş enerjisi panelleri ve evlerden çekilen kablolarla da karşılanabilmektedir.

Şehirleşme, orman kesimi, böceklenmeye karşı ilaç kullanımı (pestisitler), arılara zarar vermektedir. Mera alanlarının azalması, herbisitler, fungisitler (zararlı mantar ilac1) arıların yaşam sürelerini azaltmaktadır. Arılar nektar ve polen toplayamadıklarından açlıktan büyüyemezler (Kaftanoğlu, 2017). Arılıkların yakınlarında $\% 22$ oranında tarım ilacı kullanılmış olup bu işletmelerdeki arıların \%50,4'ünde koloni ölümleri gerçekleşmiştir. Böcek öldürücü olarak bilinen insektisitler; başta tarımsal zararlılar olmak üzere, ürün ve tohum depolama, hayvanlarda ekoparazit mücadele, yerleşim alanları, insan ve hayvan barınakları gibi bir çok alanda günümüzde yaygın olarak kullanılmaktadır. Bu nedenle arılar insektisitlerle sürekli ve yaygın biçimde temas ve bulaşma halindedir ve kovana taşınabilmektedir. İlaç kovanda aktif hale gelerek yavru ve ergin arı ölümlerine sebep olmaktadır (Güler, 2017). Orman köylerinde fındık, çay ve tarla sebzeciliği yapıldı̆̆ından ve fındık bahçelerinin alt temizliğinde herbisitler kullanıldığından arılar ilaçlamaya ve gübrelemeye maruz kalmaktadır, kolonilerde tamamen 
ölümler gerçekleşmese bile kısmen tarlacı arıların ölmeleriyle kovanın gücünün zayıflaması ve kovan verimliliğinin azalması bakımından sorun oluşturmaktadır. İşletmelerin \%84,3’ü tarımsal ilaçlamaların Tarım İl Müdürlüklerinin belirlediği günlerin dışında yapıldı̆̆ını belirtmişlerdir. Tarım ilaçlamalarında polinasyona zarar vermeyecek ilaçlar kullanılmalıdır. Arılıklarda ve bal üretim aşamalarında hijyen koşullarına dikkat edilmelidir.

Arıcıların \%93,9'u ballı bitkileri tanımaktadır. Arılıkların yakınlarında bal ormanı bulunma durumuna baktığımızda sadece \%17,6'lık bir işletme bal ormanlarından faydalanabilmektedir. \%82,4 gibi büyük bir çoğunluk bal ormanlarından faydalanamamaktadır. Trabzon Orman Bölge Müdürlüğü çalışma alanında 2013-2018 yılları arasında 15 adet bal ormanı kurulmasına rağmen, arıcıların \%89,1'i bal ormanlarını ulaşım yetersizliği, mevcut yolların bozuk olması ve kapasitelerinin yetersiz olmasından dolayı yeterli bulmadıklarını belirtmişlerdir. Bölgemiz de kurulan bal ormanlarının yeterli duruma gelebilmesi için ulaşım koşulları iyileştirilmeli ve bal ormanı sayısı arttırılmalıdır. Bal ormanlarındaki bal verimini arttırılabilmesi için de otsu, çalı ve ağaçcık formunda olan ballı türler ile zenginleştirilmelidir. Silvikültürel uygulamalarıyla bal verimi yüksek olan bitkilerin devamlılığ sağlanmalıdır. Ayrıca nektar ve polen bakımından zengin fakat ulaşımı zor olan yerlerin ulaşım sorunları çözülerek ya da mevcut yollar iyileştirilerek bu kaynaklar ekonomiye kazandırılmalıdır.

Ballarında kalıntı analizi yaptırılma durumuna bakıldığında; orman köylerindeki arıcıların \%75,9'unun kalıntı analizi yaptırmadığı tespit edilmiştir. Akredite olmuş labaratuvarlarda analiz paketlerine (PAK) göre fiyat listesi; PAK-01; 325 TL+KDV, PAK-2; 800 TL + KDV olarak yapılmaktadır. Bal analizi ve kalıntı analizi ücretlerinin küçük işletmeler için yüksek olmasından dolayı bal ve kalıntı analizi yaptırılmadan ballar pazarlanmaktadır. Bal ve kalıntı analizleri Tarım ve Orman Bakanlığı, Gıda Kontrol Labaratuvarlarında da ücret karşılığında yapılmaktadır. Ballarında kalıntı analizi yaptıran 126 kişi çoğunlukla Hacettepe Üniversitesi, Rize Arıcılar Biriliği, Trabzon Arıcılar Birliği ve Eğe Üniversitesine yaptırdıklarını belirtmişlerdir. Bal analizi ve kalıntı analizi ücretlerinin ödenmesi kısmen ya da tamamen ilgili kurumlar tarafindan karşılanabilmesi için Tarım Orman Bakanlığı ve OGM ilgili diğer birimleri başta olmak üzere devlet tarafından düzenlemeler yapılmalıdır. Üreticilerin balları, Kooperatifler ve Birlikler aracılığıyla analiz yapıldıktan sonra balların dolumu veya paketlemesi yapılarak pazarlanmalıdır.
Pazarlanan arı ürünlerinde ilk sırada \%59,7 ile süzme bal gelmektedir. Petekli balın satılması hem petek üzerindeki tüm ilaç kalıntılarının tüketilmesi açısından hemde petek tüketimi ile piyasadaki mum fiyatının artması açısından sorun oluşturmaktadır. Polen pazarlaması ise yok denecek kadar azdır. Arı ürünleri pazarlanırken \%93,5 oranında "Perakende olarak tanıdıklarıma pazarlıyorum." yöntemi, \%3,8 ile de "Arı Yetiştiricileri Birliği aracılığıyla pazarliyorum." yöntemini kullanmaktadır. Bulgularımız, Coşgun ve Güler, (2014)'in ve Saner G., (2005)'İ çalışmları ile benzerlik göstermiştir. $\mathrm{Bu}$ pazarlamada üreticilerin en çok kullandıkları yöntem ürünlerini bizzat kendileri veya tanıdıkları aracılığıyla satmalarıdır. İşletmelerin \%25,4’ü pazarladıkları ürün az olduğundan pazarlamada herhangi bir sorunla karşılaşmadıklarını belirtmişlerdir. \%13,4’ü pazara kontrolsüz ürün girmesine bağlı olarak piyasada sahte balların özellikle Rize iline Gürcistan'dan menșei bilinmeyen bal getirilerek piyasada sahte bal olarak satılması, Bayburt ilinde diğer illerden ve hatta yurt dışından getirilen balların Bayburt balı markasılla satılması, önemli turizm yörelerinde Anzer balı (Rize) adı altında sahte balların yüksek fiyatlarla satılması yerli üreticiyi olumsuz yönde etkilemektedir. Ar1 ürünlerinin bilinirliği ve tüketicilerin bal tüketiminin arttırılabilmesi için fuar ve festivallere katılım ve kamu spotu gösterimler yapılmalı, piyasadaki sahte bal reklamından bal kalitesi üzerine yaşanan güvensizlikten dolayı markalı balların tercih edilmesini özendirici reklamlar yapılmalıdır.

Arıcıların \%92'si hayatlarının bir döneminde ar1c1lık konusunda eğitim gördüğünü, \%89,5'inin arıcılık sertifikası olduğunu belirtmiştir. \%83,2'si arıc1lık faaliyetlerinde daha fazla bilgi talep etmiştir. En fazla \%53.1'ile "Arı hastalıkları ve ilaç kullanımı" ( arı sağlığının korunması ve arıcılıkta karşılaşılan hastalıklar için kullanılacak ilaçlar konusu), \%23,9 ile "Genel arıcılık" (arı yetiştiriciliğinin genel konuları), \%12,4 ile "Ana arı ve ar1 ürünleri üretimi” ( ana arı yetiştiriciliği ve polen, propolis, arı sütü üretimi), \%10,6 ile verimli ve teknik arıcılık, (uygun arılık yeri, yüksek verimli arı ırkları, doğal koşulların elverişliliği, arıcılık bilgi ve deneyimiyle birlikte modern araç ve gereçlerle yapılan arıc1lık) konularında uygulamalı eğitim almayı talep etmektedirler.

Ar1 yetiştiriciliğinde karşılaştıkları sorunun çözümü için yeterli bilgi sahibi olmadıklarını bunun içinde işletmecilerin \%70,4'lik kısmının arıcılıkla ilgili araştırma yaptığı tespit edilmiştir. Kitap, dergi, televizyonun çiftçilere yönelik kanallarının yanı sıra \%43'ü de internet ortamından araştırma yaparak sorunlarını gidermeye çalışmaktadır. Arı- 
cıların bilgi eksikliğini giderebilmesi için ve güncel durumu takip edebilmesi için kamu kurumları ve özelliklede Arı Yetiştiricileri Birlikleri tarafından eğitim verilmesine rağmen yeterli ve ihtiyac1 karşılayacak nitelikte olmamaktadır.

Kozmetik, gıda ve sağlık alanında kullanılabilecek katma değeri yüksek arı ürünleri üretiminin arttırılabilmesi için, uygulamalı eğitimler düzenlenerek arı yetiştiricileri eğitilmeli ve bu ürünleri üretenler desteklenmelidir. Eğitimler sahada uygulamalı verilmelidir. Eğitimler görsel olarak televizyon programlarından sürekli yayınlanmalıdır. Tarım İlçe Müdürlükleri bünyesinde arıcılık faaliyetlerinde karşılaşılan sorunlar için uzman personeller istihdam edilmelidir.

Sonuç olarak; yapılan çalışmanın verileri doğrultusunda, arıcıların sorunlarına çözüm önerileri getirilmiş olup, teknolojiye bağlı talepleri dikkate alınarak, ORKÖY fenni arıcılık kredi desteklerine düzenlenme getirilmelidir.

Not: Bu makale, 2013-2018 yıllarında T.C. Orman Bakanlığı, Orman Genel Müdürlüğü, Doğu Karadeniz Ormancılık Araştırma Enstitüsü Müdürlüğünce "Orman Köylerinde Arıcılık Sorunları ve Çözüm Önerileri (Trabzon Orman Bölge Müdürlüğü Örneği)" başlığıyla gerçekleştirilen araştırma sonucunda hazırlanan ve OGM Araştırma İhtisas Grupları Toplantısında yayınlanması yönünde karar verilen proje sonuç raporunun bir bölümüdür.

\section{Kaynaklar}

Anonim 1, OGM, 2017. T.C. Orman ve Su İşleri Bakanlı̆ğ, Orman Genel Müdürlüğü, Bal Ormanı Eylem Planı 2013- 2017.

Anonim 2, OBM, 2015. Trabzon Orman Bölge Müdürlüğü, ORKÖY Şube Müdürlüğü, Fenni Arıcılık Destekleme kayitları.

Anonim 3, 2017. 45. Apimondia (Milletlerarası Arıc1lar Federasyonu) Dünya Arıcılık Kongresi 29 Eylül-4 Ekim, 2017, İstanbul-Türkiye.

Bölüktepe, F. E, Yılmaz, S., 2008. Ar1 Ürünlerinin Bilinirliği ve Satın Alma Sıklığı. Uludağ Arıcılık Dergisi, Cilt:8, Say1:2, Sayfa:53-62 Bursa.

Coşgun., U., Güler, K. H., 2015. Arıcıllk Yapanların İşletme Ekonomisi Açısından İncelenmesi (Batı Akdeniz Orman Köyleri Örneği). Batı Akdeniz Ormancılık Araştırma Müdürlüğü, Sonuçlanan Proje Sonuç Raporu, 88 sayfa, Antalya.

Daşdemir, İ., 2016. Bilimsel Araştırma Yötemleri, Nobel Akademik Yayıncılık ve Danışmanlık Tic. Ltd. Şti. Yayın No: 1536, 210 s, Ankara.
DOKAP, 2014. T.C. Kalkınma Bakanlığ1 Doğu Karadeniz Projesi Bölge Kalkınma İdaresi Başkanlığı, Arı ve Arı Ürünleri Üretimi Faaliyetlerinin Doğu Karadeniz Illerinde Geliştirilerek Yaygınlaştırırlması Projesi, Giresun.

Doğaroğlu, M., Doğaroğlu, O.K., 2015. Modern Arıcılık Teknikleri, 2015, 6. Basım, Anadolu Matbaası, İstanbul.

Erkan, C., Aşkın, Y., 2001. Van ili Bahçesaray İlçesinde Arıcılığın Yapısı ve Arıcılık Faaliyetleri. Yüzüncü Yll Üniversitesi, Ziraat Fakültesi; Tarım Bilimleri Dergisi (J. Agric. Sc;). 2001, 11 (1):19-28.

Güler, A., 2017. Bal Arısı (Apis mellifera L.) Yetiştiriciliği, Hastalıkları ve Ürünleri. Bereket Akademi Yayınlar1, Azim Matbaacılık, Ankara, 419s.

Kavak, G., Biyik, S., Güler, A., 2015. Son Yıllarda Görülen Koloni Kayıplar1 ve Muhtemel Sebepleri. Uludağ Arıcılık Dergisi, Mayıs 2015, 15 (1):33-40.

Kaftanoğlu, O.,2017. 45. Arıcılığın Geleceği. Apimondia Dünya Arıcılık Kongresi.Sözlü Bildiri, 29 Eylül-4 Ekim, 2017/ İstanbul-Türkiye.

Kekeçoğlu, M., Gürcan, E. K. ve Soysal, M. İ., 2007. Türkiye Ar1 Yetiştiriciliğinin Bal Üretimi Bakımından Durumu, Tekirdăg Ziraat Fakültesi Dergisi, 4 (2): $227-$ 236.

Ozkirim, A.,2017. Comperative Analysis of Winter Losses of Honey Bee Colonies in Turkey 2016-2017 period with COLOSS Monitoring Data.45 th Apimondia İnternational Apicultural Congress. September 29-October 4. 2017 /İstanbul-TURKEY. Abstroct Book.P.62

Özdamar, K., 2001. Paket Programlar ve İstatistiksel Veri Analizi (Cok Degiskenli Analizler). (4. Baski), Kaan Yayinlari, Eskisehir.

Saner G., 2005. İzmir ve Muğla İllerinde Faaliyet Gösteren Arıcılık İşletmelerinin Teknik ve Ekonomik Yapısı ile Sorunların Üzerine Bir Araştırma. Birinci Bask1. İzmir: Ege Üniversitesi Yayınlar1, 2005; p. 77-80.

Seven, İ., Akkiliç, M.E., 2005. The Solution Suggestions and Detamination of Production and Marketing Problems of Beekeeping Enteprises in Elazı̆̆. Province. Lalahan Hayvancılık Araştırma Enstitüsü Dergisi 45 (2): 41-52.

Şeker, İ., Köseman, A., Karlidağ, S., Aygün, S., 2017. Arıcılık Faaliyetleri 2. Malatya İlinde Arıcılık Faaliyetlerinin Yetiştirici Tercihler, Üretim Nitelikleri ve Ar1 Hastalıkları Kapsamında Değerlendirilmesi. Tekirdağ Ziraat Fakültesi Dergisi, 2017: 14 (02), 54-63.

Soysal, M.İ., E.K. Gürcan, 2005. Tekirdağ İli Ar1 Yetiştiriciliği Üzerine Bir Araştırma. Tekirdağ Ziraat Fakültesi Dergisi, 2005, S. 2(2),161-165.

Tunca, R.İ. Çimrin, T., 2012. Kırşehir İlinde Bal Arıs1 Yetiștiricilik Aktiviteleri Üzerine Anket Calıșması. Iğdır Üniversitesi Fen Bilimleri Enstitüsü Dergisi 2 (2) (2012) 99-108. 
URL 1, 2015. http://www.fao.org/faostat/on\#data (Erişim tarihi: 12.10.2018).

URL 2, 2018. https://biruni.tuik.gov.tr/hayvanc1l1kapp/ hayvancilik.zul

(Erişim tarihi:12.10.2018).

URL 3, 2018. https://koy.ogm.gov.tr (Erişim tarihi: 15.10.2018).

URL 4, 2018. https://ogm.gov.tr (Erişim tarihi: 12.10.2018).

URL 5, 2015. https://koy.ogm.gov.tr (Erişim tarihi: 07.02.2015).
URL 6, 2017. www.resmigazete.gov.tr/ eskiler/2017/08/20170818M1-27.pdf (Erişim tarihi: 07.02.2015)

URL 7, 2017. www.antalyaaricilarbirligi.com/petek/ (Erişim tarihi:12.10.2018).

Uzundumlu, A.S., Aksoy, A., Işık, H.B., 2011. Arıc1lık İşletmelerinde Mevcut Yapı ve Temel Sorunlar: Bingöl İli Örneği. Atatürk Üniv. Ziraat Fak. Dergisi. 42 (1) 4955.

Yaşar, N., Güler, A., Yeşiltaş, H. B., Bulut, G., Gökçe, M., 2002. Karadeniz Bölgesi Arıcılığının Genel Yapısının Belirlenmesi. Mellifera, 2-3: 15-24. 